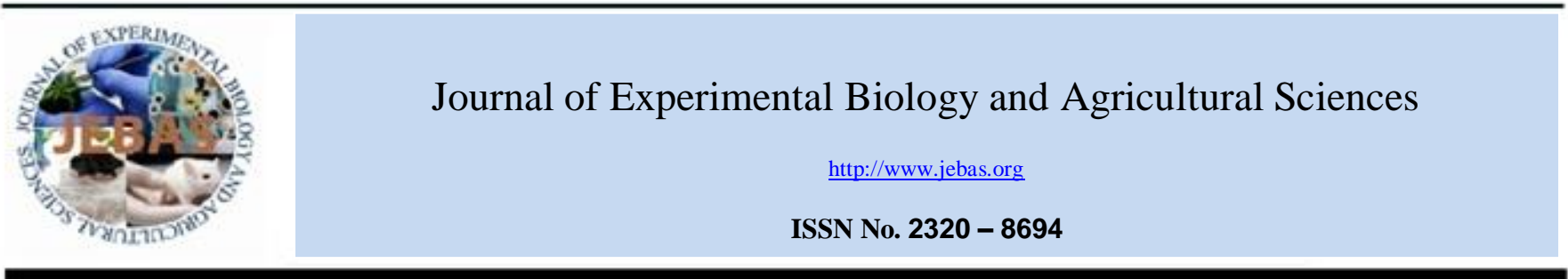

\title{
ANTIOXIDANT POTENTIAL IN RELATION TO TOTAL PHENOLICS AND PIGMENT CONTENTS AMONG THE SELECTED LANDRACES OF Dioscorea alata L. IN KERALA, INDIA
}

\author{
Anumol Jose, Sajna Nizar, Vishnu MR, Anil Kumar M* \\ Department of Botany, Union Christian College, Aluva, Kerala, India. Pin-683102.
}

Received - May 16, 2019; Revision - June 20, 2019; Accepted - July 11, 2019

Available Online - August 05, 2019

DOI: http://dx.doi.org/10.18006/2019.7(4).403.410

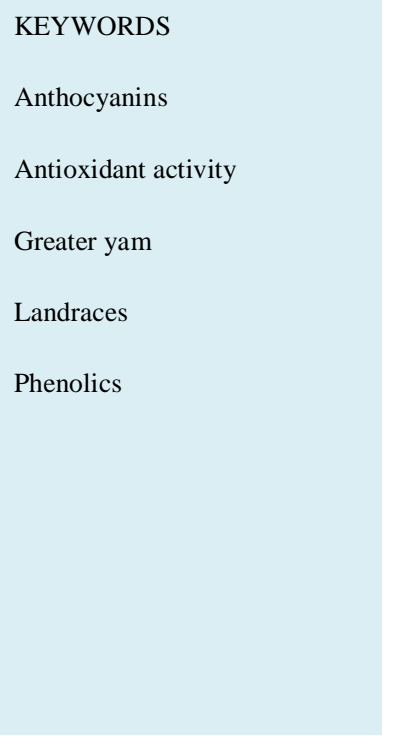

\begin{abstract}
The present study aims to evaluate and compare the phenolics, pigment content and antioxidant potential of the four landraces of Dioscorea alata prevalent in Kerala. Dioscorea alata (greater yam) is an underutilized, food security crop that exhibits wide variability in morphological, biochemical and agronomical traits. One of the distinct morphological features that varied among landraces of D. alata is tuber flesh colour which ranged from white, yellow, pink and purple. CIELAB coordinates of each tuber colour were estimated using reflectance spectroscopy and represented in $\mathrm{L}^{*} \mathrm{a} * \mathrm{~b} *$ values. Quantification of total phenolic compounds and pigments were done spectroscopically using standard protocols. Antioxidant activity of the tuber extracts were estimated using 1,1-Diphenyl-2-picryl hydrazyl (DPPH) quenching assay and ferric reducing antioxidant power (FRAP) assay. Total phenol and flavonoid content in yellow and purple-fleshed $D$. alata were significantly higher than white and pink fleshed landraces. Spectrophotometric assays revealed the differential expression of anthocyanins and carotenoids in tubers, which corresponds to the colour difference among different landraces. Antioxidant activity based DPPH and FRAP assay were significantly different among the four landraces. Yellow and purple-fleshed landraces shared high antioxidant activity and was positively correlated with the phenolic and pigment contents. The study also listed certain morphological features that aid in identifying the landraces of D. alata.
\end{abstract}

* Corresponding author

E-mail:drmakumar@gmail.com (Anilkumar M)

Peer review under responsibility of Journal of Experimental Biology and Agricultural Sciences.

Production and Hosting by Horizon Publisher India [HPI] (http://www.horizonpublisherindia.in/).

All rights reserved.
All the articles published by Journal of Experimental Biology and Agricultural Sciences are licensed under a Creative Commons Attribution-NonCommercial 4.0 International License Based on a work at www.jebas.org.

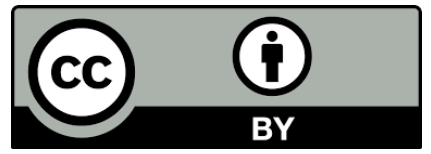




\section{Introduction}

Dioscorea alata, commonly known as greater yam, is an underutilized and climate resilient crop widely cultivated in tropical and subtropical countries (Bressan et al., 2011). This plant belongs to the genus Dioscorea of family Dioscoreaceae and being a subsistent food crop it is well known for the close relationship with human civilization. But, changed food habits and agricultural practices in the modern world turned this crop as a less preferable one and subsequently it's status shifted to the underutilized category (Siqueira, 2017). The edible underground tuber of greater yam is rich in carbohydrates and other nutritionally important secondary metabolites. Major bioactive components present in greater yams included proteins, polyphenols, carotenoids, alkaloids and phytosterols (Lubag et al., 2008). Owing to the presence of these bioactive molecules, greater yam was reported to possess antiinflammatory, anticancerous, antiobesity and antibacterial properties (Das et al., 2014; Jesus et al., 2016; Chen et al., 2017). The pharmacological and biological properties of greater yams have been attributed to the chemoprotective antioxidants. Antioxidants are molecules that at low concentration delays oxidation of nucleic acids, carbohydrates, lipids, and proteins (Holick et al., 2002; Forbes-Hernández et al., 2017). Antioxidants as food supplements impart health benefits in various conditions like stress, aging, pathogen infestation, apoptosis, and neurodegenerative diseases (Sindhi et al., 2013). Phytoconstituents such as polyphenols, carotenoids and alkaloids were known to possess antioxidative properties. Quantitative analysis of phytochemicals present in the plants could be reliable measure of its antioxidant property (Tang et al., 2015). Yam species exhibits considerably high antioxidant properties, thus making them an economically important crop in the modern scenario (Ukom et al., 2014). New developments and promising investigations in this area can elevate the agricultural preference of this neglected crop.

In India, 50 species of Dioscorea were reported from southern and north eastern hill regions of which 17 were distributed in Western Ghats (Kumar et al., 2017). Kerala is geographically located at the southwest edge of India and is known for its tropical climate ideal for the growth and propagation of Dioscorea species. D. alata is the most common yam present in Kerala and exhibits a broad spectrum of variability in morphological, agronomical and biochemical traits (Jyothi et al., 2017). Such variable morphotypes were considered as landraces and were known by different vernacular names. Even though an integral part of traditional agriculture in tropical and subtropical countries, landraces of D. alata were least explored and remain neglected.
One of the distinct morphological feature useful to identify these landraces were their tuber flesh colour that ranged from white to yellow, pink and purple. It was reported that there were measurable variations in the starch and protein content of these landraces, but the data available regarding the bioactive compounds and the potential antioxidative properties in them were scanty. The present investigation is an attempt to correlate the antioxidant property of selected land races of $D$. alata with the total total phenolics, flavonoids, carotenoids, and anthocyanins.

\section{Materials and Methods}

TPTZ (2,4,6-tripyridyl-s-triazine), $\mathrm{FeSO}_{4} \cdot 7 \mathrm{H}_{2} \mathrm{O}$ (iron (II) sulfateheptahydrate) and 1,1-Diphenyl-2-picrylhydrazyl (DPPH) were purchased from Sigma Chemicals, USA. Aluminum chloride, FolinCio-Calteus's phenol reagent, sodium carbonate, $\mathrm{FeCl}_{3}$, gallic acid, ascorbic acid and hydrochloric acid were purchased from Merck. All the chemicals used including the solvents were of analytical grade.

\subsection{Plant materials}

Landraces of greater yams, which showed distinct colour differences in their tuber flesh, were collected from local farmers of Kerala. Morphological characterization and species identification were done according to the norms of IPGRI (IPGRI, 1997). Forty-five accessions of D. alata were maintained in the field as germplasm and the tuber colour was observed and documented at the end of growing seasons. Four landraces, which expressed stable white, yellow, pink and purple flesh colours for three consecutive growing seasons were selected for the study. Details of the accessions were given in table 1 .

Table 1 Accessions of Dioscorea alata collected from Kerala

\begin{tabular}{|cccc|}
\hline $\begin{array}{c}\text { Accession } \\
\text { number }\end{array}$ & Local name & $\begin{array}{c}\text { Place of } \\
\text { collection }\end{array}$ & $\begin{array}{c}\text { Flesh } \\
\text { colour }\end{array}$ \\
\hline KLE DA 01 & Chorakachil & Ernakulam & Purple \\
\hline KLI DA 12 & Rosakamban kachil & Idukki & Pink \\
\hline KLP DA 08 & Parakachil & Pathanamthitta & Yellow \\
\hline KLK DA 10 & Bharanikachil & Wayanad & White \\
\hline
\end{tabular}

\subsection{Morphological Characterization of Accessions}

Morphological characterization was done as per the methods given by International Plant Genetic Resources Institute's descriptor list (IPGRI/ IITA, 1997). The accessions were analyzed for distinct qualitative and quantitative characters. Only those features that 
discriminated between the accessions were used for the present analysis. Data were collected in triplicates from at least three different healthy plants of each accession and then averaged.

\subsection{Extraction of phenolics compounds and pigments}

Phenolics, flavonoids, anthocyanins and carotenoids were extracted from the tuber as per method given by Ferede et al. (2010) and Fang et al. (2011). For the extraction of phenolics and flavonoids, one gram tuber flesh devoid of skin was homogenized in $10 \mathrm{ml}$ of $60 \%$ ethanol and the supernatant was collected. The residue was re-extracted thrice and all the supernatants were pooled. For anthocyanin isolation, $60 \%$ ethanol acidified with $0.2 \% \mathrm{HCl}$ was used. Carotenoid extraction was carried out by using $90 \%$ ethanol.

\subsection{Biochemical estimations}

Estimation of phenol, flavonoid, total anthocyanins and carotenoids were carried out according to the standard protocols. Each experiments were triplicated and the average values taken for analysis.

\subsubsection{Total Phenol and flavonoid Estimations}

The total phenolic contents of tuber extracts were determined using the Folin-Ciocalteau method (Sellappan et al., 2002). Quantification was based on gallic acid calibration curve and the results were expressed as gallic acid equivalents per 100gram of fresh tissue. The results were averages of triplicate analysis.

The total flavonoid content was determined using Aluminium chloride assay (Zhishen et al., 1999; Pekal \& Pyrzynska, 2014). $0.5 \mathrm{ml}$ of $2 \% \mathrm{AlCl}_{3}$ - ethanol solution was added to $0.5 \mathrm{ml}$ of the sample mixed with $150 \mu 1$ of $5 \%$ sodium nitrite. After six minutes of incubation, $2 \mathrm{ml} 1 \mathrm{~N} \mathrm{NaOH}$ solution mixed and further incubated for 15 minutes. The absorbance of the mixture was measured at $510 \mathrm{~nm}$. Total flavonoid content was determined with the help of the calibration curve of quercetin and results were expressed as quercetin equivalents per gram of fresh tissue. The experiment was repeated thrice and averages were taken.

\subsubsection{Anthocyanin and carotenoid estimations}

Total anthocyanin content (TAC) was estimated by spectrophotometric pH differential method (Guisti \& Wrolstad, 2005). The absorbance of tuber extract at 520 and $700 \mathrm{~nm}$ was measured using a UV-Visible Spectrophotometer (Shimadzu, Japan). Pigment content was calculated as Cy-3-glu equivalents using the following formula

Total Anthocyanins $(\mathrm{mg} / \mathrm{L})=A \times M W \times D F \times 1000 / \varepsilon \times I$

Where $A=$ Absorption at 520; $M W=$ Molecular Weight of cyanidin-3-glucoside(449.2); DF = Dilution Factor; $\varepsilon=$ molar extinction coefficient of Cyanidin -3- glucoside $(26900 \mathrm{~L} / \mathrm{cm} / \mathrm{mg})$
Total carotenoid content was determined from the absorbance measured at $450 \mathrm{~nm}$ on a Vis-spectrophotometer and was quantitatively estimated using the formula suggested by Rodriguez-Amaya \& Kimura (2014).

Total carotenoid content $(\mathrm{mg} / \mathrm{g})=\mathrm{A} \times$ Volume of extract in $\mathrm{ml} \times$ $1000 / \varepsilon \times$ sample weight in $\mathrm{g}$

\section{Where $A=$ absorbance; $\varepsilon=$ absorption coefficient (2500 L/cm/mg)}

\subsection{Measurement of colour coordinates}

Reflectance spectrum of tuber samples was taken using UV spectrometer with integrated sphere attachment (2800 plus, Schimadzu, Japan) and the $\mathrm{L}^{*} \mathrm{a}^{*} \mathrm{~b}^{*}$ coordinates calculated from the spectrum using colour analysis software (Shimadzu).

\subsection{Antioxidant activity analysis}

DPPH radical scavenging activity was estimated as per previous reports (Yu et al., 2002; Sing et al., 2002; Tang et al., 2015). For this, $100 \mu \mathrm{l}$ of the sample extract was added to $2.9 \mathrm{ml}$ of DPPH reagent in ethanol and vortexed vigorously. It was incubated in dark for $30 \mathrm{~min}$ at room temperature and the discolouration of DPPH was measured at $517 \mathrm{~nm}$. Percentage inhibition on the discolouration of DPPH by the sample extract was expressed as ascorbic acid equivalents.

Ferric reducing antioxidant power (FRAP) was determined in the sample extracts according to previous reports (Abu Bakar et al., 2016). $3.0 \mathrm{ml}$ of FRAP reagent was added to the known concentration of the sample extract. After six minutes of incubation at room temperature, the absorbance was measured at $593 \mathrm{~nm}$ against ascorbic acid standard.

\subsection{Statistical analysis}

The experimental results were expressed as mean \pm standard deviation of three replicates and was subjected to one-way analysis of variance (ANOVA) followed by post-hoc analysis by tukey t-test (SPSS statistics version 20). P values $\leq 0.05$ were regarded as significant. The correlation coefficient ( $\mathrm{R}$-value) was calculated using Microsoft Excel software.

\section{Results and Discussion}

\subsection{Analysis of morphological features}

Morphological features which prevailed stable for three consecutive growing seasons were analyzed and documented. Distinct and prominent features observed among accessions were summarized in table 2.Young leaves were of purple in all the accessions, which exhibited colouration in tuber flesh while it was 
Table 2 Morphological variations in selected D. alata accessions from Kerala

\begin{tabular}{|c|c|c|c|c|}
\hline Character & $\begin{array}{l}\text { KLE DA } 01 \\
\text { (Purple) }\end{array}$ & $\begin{array}{l}\text { KLI DA } 12 \\
\text { (Pink) }\end{array}$ & $\begin{array}{l}\text { KLP DA } 08 \\
\text { (yellow) }\end{array}$ & $\begin{array}{l}\text { KLY DA } 10 \\
\text { (White) }\end{array}$ \\
\hline Young leaf colour & Purplish green & Purple with green tips & Purplish green & Brownish green \\
\hline Leaf shape & Cordate broad with cupping & Sagittate long & Cordate long with cupping & Cordate long without cupping \\
\hline Tuber shape & variegated & Round & Variegated & cylindrical \\
\hline Tuber cortex colour & Dark purple & Dark purple & Light purple & light brown \\
\hline Tuber flesh colour & Purple & Pink & Yellow with white patches & White \\
\hline Tuber skin texture & Highly warty & Smooth & Warty & warty \\
\hline Presence and nature of spine & No spine & No spine & $\begin{array}{l}\text { Purple short spines at the base } \\
\text { of young stem }\end{array}$ & No spine \\
\hline Presence of stem patches & No stem patches & No stem patches & Purple long patches on young stem & No stem patches \\
\hline
\end{tabular}

Data were the average of at least three different healthy plants per accessions

brownish green in the white fleshed tuber. Pink-fleshed D. alata plants showed a distinct green coloured tip on their purple young leaf. Cordate and sagittate leaf shapes were frequently observed in D. alata accessions. Among different accessions, cordate shape again varied due to the presence or absence of cupping formed by the overlapping of leaf lobes. Pink-fleshed D. alata were distinct among the selected accessions due to the presence of sagittate shaped leaves and round shaped tuber with smooth skin. Tuber cortex colour expressed shades of purple in three accessions but was brown in the case of the yellow-fleshed tuber. Presence of spin and purple patches in the stem differentiates yellow fleshed yam from other accessions. According to IPGRI norms, 47 descriptors were used for morphological characterization of Dioscorea species (Hasan et al., 2008). Being the most polymorphic species in the genus Dioscorea, landraces of D. alata showed many overlapping morphological characteristics (Anokye et al., 2014). The quantitative features of $D$. alata landraces were found to be unstable compared to qualitative characters. Hence the present study was focused only on qualitative characters which were distinct among different accessions. Morphological features such as mature leaf colour, the presence of bulbil, colour of ridge, petiole colour, colour of leaf margin and shape of stem cross section were evaluated and found to be unstable over growing seasons. In this juncture, focus has been given only to 8 qualitative characters which were relevant in identifying landraces of D. alata. Results suggested that young leaf colour, leaf shape, colour of tuber cortex and flesh, shape of tuber and stem characteristics such as the presence of spine and patches could be useful in identifying the landraces of greater yam. These morphological features were reported to be important in analysing morphological diversity among landraces of $D$. alata distributed in Ivory Coast, Vietnam, Ethiopia and Brazil (Bressan et al., 2011; Michel et al., 2015; Tewodros et al., 2018).

\subsection{Colour Characteristics of tubers}

The colour values of greater yam tubers from five landraces were presented in Table 3. CIE L*a*b* colour system (CIELAB) based on reflectance spectroscopy was adopted for the quantification of colour. The $\mathrm{L}^{*} \mathrm{a} * \mathrm{~b} *$ coordinates described in the present study indicates $\mathrm{L}^{*}=$ 0 as black and $\mathrm{L}^{*}=100$ as white and the $\mathrm{a}^{*}$ and $\mathrm{b}^{*}$ represents position between red $(+)$ and green $(-)$, and yellow $(+)$ and blue $(-)$ respectively (Tang et al., 2015). Raw tubers of the five landraces showed distinct colour variations both visually and in terms of colour coordinates. These colour differences in landraces may occur due to the presence of several types of pigments, such as anthocyanins and carotenoids. Anthocyanins impart pink and purple colour while carotenoids were responsible for yellow colour (Davies et al., 1998; Berman et al., 2016). The flesh colour variations in the D. alata landraces from white to different shades of purple by visual observations were reported earlier (Jyothy et al., 2017). Colour quantification using CIELAB coordinates help to identify the exact colour tone of $D$. alata landraces with accuracy and repeatability.

Table 3 CIELAB Colour coordinates of yam tuber flesh

\begin{tabular}{|cccc|}
\hline $\begin{array}{c}\text { Accessions and tuber } \\
\text { flesh colour }\end{array}$ & $\mathrm{L}^{*}$ & $\mathrm{a}^{*}$ & $\mathrm{~b}^{*}$ \\
\hline KLK DA 10 (white) & $93.9 \pm 0.03$ & $0.11 \pm 0.3$ & $7.3 \pm 0.5$ \\
\hline KLP DA 08 (Yellow) & $82.6 \pm 0.03$ & $2.21 \pm 0.02$ & $580 \pm .5$ \\
\hline KLI DA 12 (Pink) & $70.33 \pm 0.4$ & $36.8 \pm 0.3$ & $2.71 \pm 0.3$ \\
\hline KLE DA 01 (Purple) & $45.5 \pm 0.2$ & $50.45 \pm 0.6$ & $42.8 \pm 0.3$ \\
\hline
\end{tabular}

Data were the average of three tubers per accessions 

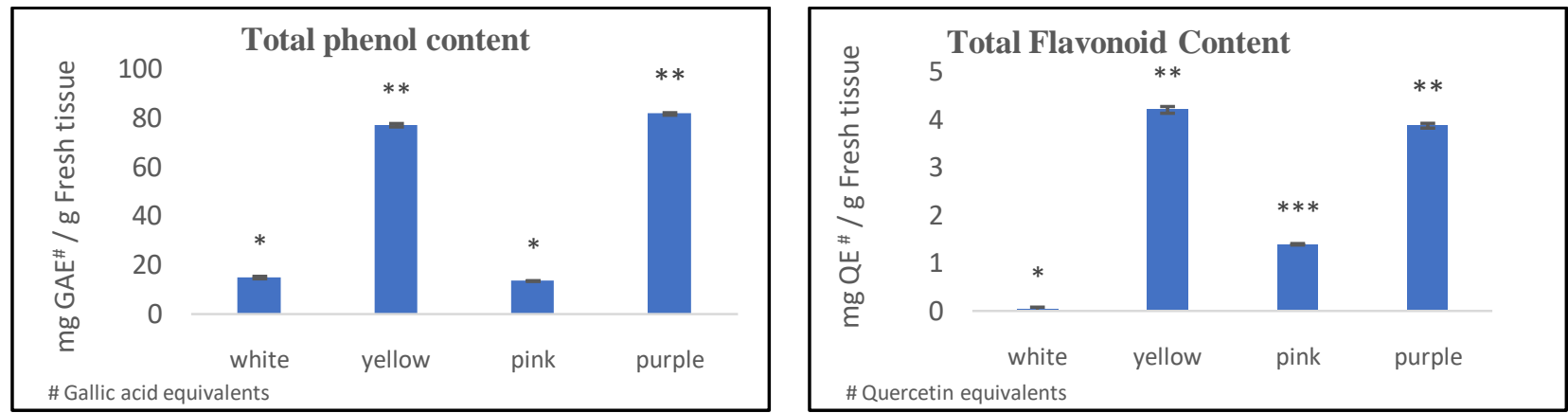

Data are represented as mean $\pm S D(N=3)$ Columns belonging to the same set of data with different superscript characters are significantly different $(p<0.05)$.

Figure 1 Total Phenolics and flavonoid content in greater yam landraces
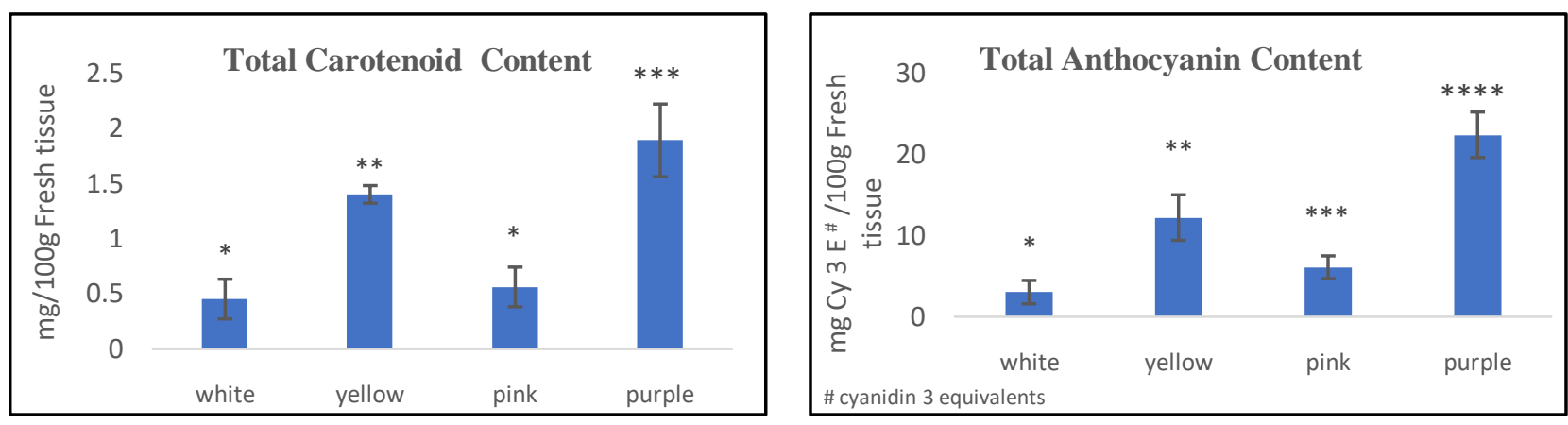

Data are represented as mean $\pm S D(N=3)$. Columns belonging to the same set of data with different superscript letters are significantly different $(p<0.05)$.

Figure 2 Total carotenoid and anthocyanin content in greater yam landraces

\subsection{Total Phenolics and Flavonoid}

The total phenolic and flavonoid contents were significantly varied among differentially coloured tubers of D. alata (Figure 1). White and pink-fleshed landraces expressed significantly lower phenolic and flavonoid contents compared to others. Phenol and flavonoid contents in yellow and purple-fleshed landraces were comparable and higher than pink and white landraces. This suggested that yellow and purplefleshed greater yam landraces were nutritionally superior to others. Plant-derived phenols and flavonoids were considered as dietary antioxidants that impart beneficial implications in human health (Bravo, 1998). Previous studies established that D. alata contains a substantially increased amount of phenols and flavonoids in its tuber (Sajjaanantakul et al., 2014). In the present investigation, there were significant variations in the total phenolic content among the landraces of D. alata and it was positively correlated with the tuber colour imparted by different pigments. The extent of these variations was found to be almost three-fold which clearly indicated the nutritional superiority of coloured tubers of D. alata. Phenolic composition of yellow and purple yam was equivalent to that of drumstick, cabbage, and cluster beans (Sreeramulu \& Raghunath, 2010). Present results also confirmed that the amount of phenols present in yams was equal and even higher than most of the vegetables consumed by people.

\subsection{Total anthocyanin and carotenoid}

Anthocyanins and carotenoids were the pigments in yams which impart colour to its tubers. Results from the present study indicated that purple fleshed yams accumulate significantly higher amount of both pigments (Figure 2). Purple-fleshed tuber contained $22.7 \mathrm{mg}$ of anthocyanins and $1.89 \mathrm{mg}$ of carotenoids per100g of fresh tissue. In yellow fleshed landraces amount of carotenoids were less than purple fleshed tubers but appeared yellow owing to the low anthocyanin content $(12.2 \mathrm{mg} / 100 \mathrm{~g}$ of tissue). Pink-fleshed yam tubers contained both pigments in lower concentrations but due to the elevated amount of anthocyanins compared to carotenoids its colour shifted more towards red scale than yellow. White-fleshed tuber cumulates both pigment in very low concentrations and hence appeared white in colour. Both in vitro and in vivo studies have provided significant evidence on the 
potential of anthocyanins as a functional food. Anthocyanins were well known for their anti-inflammatory and anti-carcinogenic activity as well as preventive effects on cardiovascular diseases, obesity and diabetes (He \& Giusti, 2010). Carotenoids were also considered as a potential dietary component which provides health benefits in decreasing the risk of diseases, especially certain type of cancers and eye diseases (Holick et al., 2002). Being a source of both carotenoids and anthocyanins, greater yam possesses immense potential as a functional food. Our results suggested the potential of purple and yellow fleshed landraces of greater yam as a reservoir of functionally important phytoconstituents.

\subsection{Antioxidant activity and correlation analysis}

Different landraces of greater yam contained high amounts of phenol, flavonoids, anthocyanins and carotenoids which were well known for their antioxidant properties. In this context the knowledge on the extent of antioxidant activities imparted by these landraces were of prime importance. Literature suggested a number of assays that have been employed to evaluate the in vitro antioxidant activities of different plant materials, of which ferric reducing antioxidant power (FRAP) and 2, 2,0-diphenyl-1-picryl hydrazyl (DPPH) radical scavenging assays were the most common. Both of these assays rely on the use of a positive control as it clearly helps to represent the antioxidant properties of the samples. In this study, ascorbic acid was used as the positive control. In table 4 the antioxidant activity of different landraces

Table 4 Antioxidant activity of greater yam land races

\begin{tabular}{|ccc|}
\hline Sample & $\begin{array}{c}\text { DPPH scavenging activity } \\
\text { (Ascorbic acid equivalents } \\
\text { in } \mu \mathrm{m} / \mathrm{gm} \text { of fresh tissue })\end{array}$ & $\begin{array}{c}\text { FRAP activity } \\
\text { (Ascorbic acid } \\
\text { equivalents in } \mu \mathrm{m} / \mathrm{gm} \\
\text { of fresh tissue })\end{array}$ \\
\hline White & $170 \mathrm{a}$ & $68.3 \mathrm{a}$ \\
\hline Yellow & $287 \mathrm{~b}$ & $732 \mathrm{~b}$ \\
\hline Pink & $160.80 \mathrm{a}$ & $64.66 \mathrm{a}$ \\
\hline Purple & $261.18 \mathrm{~b}$ & $363.3 \mathrm{c}$ \\
\hline
\end{tabular}

Values are presented as mean values $(n=3)$. Different letters in the same column indicate significant differences $(p<0.05)$

expressed in micromolar concentrations of ascorbic acid equivalent per gram of yam fresh tissue. Yellow and purplefleshed landrace have comparatively higher antioxidant properties in terms of both assays while white and pink-fleshed landraces showed lower antioxidant activities. Similar to other studies (Brad Williams et al., 1995) FRAP assay values were proportionally different from DPPH assay values, presumably due to variations in reaction kinetics and antioxidant potentials of various reductive substrates as they interact with the two radicals (Ozgen et al.,
2010 ). Antioxidant property of yellow and purple-fleshed tubers were comparable and could be attributed to the fact that they have similar phenolic and flavonoid contents.

Correlation analysis was performed to determine the contribution of polyphenols, flavonoids and pigments towards antioxidant activities of landraces. The $\mathrm{R}^{2}$ values obtained in the analysis were listed in table 5. The results suggested that there was a strong positive correlation between the phenol content and antioxidant activity in terms of DPPH and FRAP assay values (r-value< 0.9). The total flavonoid content and antioxidant activity was also correlated positively. Even though values from the two antioxidant assay techniques were different, the data sets in this study were highly correlated. The positive correlation ( $r$ value $<0.7$ ) between antioxidant activity and pigment contents suggested their contribution towards the antioxidant activities.

Table 5 Correlation coefficient ( $\mathrm{R}^{2}$ values) of DPPH and FRAP activity $v s$ total phenol, flavonoid, anthocyanin and carotenoids

\begin{tabular}{|ccccc|}
$\begin{array}{c}\text { Antioxidant } \\
\text { activity }\end{array}$ & $\begin{array}{c}\text { Total } \\
\text { phenol }\end{array}$ & $\begin{array}{c}\text { Total } \\
\text { flavonoid }\end{array}$ & $\begin{array}{c}\text { Total } \\
\text { anthocyanin }\end{array}$ & $\begin{array}{c}\text { Total } \\
\text { carotenoid }\end{array}$ \\
\hline DPPH activity & 0.99 & 0.96 & 0.74 & 0.89 \\
\hline FRAP activity & 0.95 & 0.90 & 0.47 & 0.70 \\
\hline
\end{tabular}

\section{Conclusion}

This study documented certain distinct morphological features exhibited by four different landraces of D. alata in Kerala. The CIELAB colour coordinates were helpful in identifying tuber colour variations in the selected landraces. Among four landraces of greater yams, yellow and purple-fleshed yams showed significantly higher antioxidant activity which in turn was positively correlated to the amount of phenolics and pigments. White and pink-fleshed yams showed comparatively lower antioxidant activity and their phenol and pigment compositions were also low. This study suggested the nutritionally important biochemical properties of yellow and purple-fleshed yams. In Kerala, white-fleshed yam is more acceptable and popular as a food crop. On the contrary, the results of our study proved the nutritional superiority of yellow and purple yams over white fleshed yams. Hence, we suggest the use and cultivation of purple and yellow fleshed yams as a nutritionally rich food crop for the people of tropical and subtropical countries. Further investigation on the genetic and metabolic profile of these landraces are in progress in our lab.

\section{Conflict of Interest}

Authors would hereby like to declare that there is no conflict of interests that could possibly arise. 


\section{References}

Abu Bakar MF, Ismail NA, Isha A, Mei Ling AL (2016) Phytochemical Composition and Biological Activities of Selected Wild Berries (Rubus Moluccanus L., R. Fraxinifolius Poir., and $R$. Alpestris Blume). Evidence-Based Complementary and Alternative Medicine16:1-10.

Anokye M, Tetteh JP, Otoo E (2014) Morphological Characterization of Some Water Yam (Dioscorea alata L .) Germplasm in Ghana. Journal of Agricultural Science and Technology B Journal of Agricultural Science and Technology 4: 518-532

Berman J, Sheng Y, Gómez Gómez L, Veiga T, Ni X, Farré G, Capell T, Guitián J, Guitián P, Sandmann G, Christou P, Zhu C (2016) Red Anthocyanins and Yellow Carotenoids Form the Color of Orange-Flower Gentian (Gentiana Lutea L. Var. Aurantiaca). PLoS ONE 11: 1-20.

Brand-Williams W, Cuvelier ME, Berset C (1995) Use of a free radical method to evaluate antioxidant activity. LWT-Food science and Technology 28:25-30.

Bravo L (1998) Polyphenols: Chemistry, Dietary Sources, Metabolism, and Nutritional Significance. Nutrition Reviews 56: 317-333.

Bressan EA, Neto TB, Zucchi MI, Rabello RJ, Veasey EA (2011) Morphological Variation and Isozyme Diversity in Dioscorea Alata L. Landraces from Vale Do Ribeira. Brazil Scientia Agricola 68: 494-502.

Chen T, Hu S, Zhang H, Guan Q, Yang Y, Wang X (2017) Antiinflammatory effects of Dioscorea alata L. anthocyanins in a TNBS-induced colitis model. Food and Function 8: 659-669.

Das A, Chaudhuri D, Ghate N, Chatterjee A (2014) Phytochemical analysis, antioxidant and anticancer potential of leaf extracts from edible greater yam, Dioscorea alata L., from north-east India. International Journal of Phytopharmacology 5: 109-119.

Davies KM, Bloor SJ, Spiller GB, Deroles SC (1998) Production of Yellow Colour in Flowers: Redirection of Flavonoid Biosynthesis in Petunia. Plant Journal 13: 259-266.

Fang Z, Dan W, Dong Y, Xinqian Y, Donghong L, Jianchu C (2011) Phenolic compounds in Chinese purple yam and changes during vacuum frying. Food Chemistry 128:943-948

Ferede R, Maziya-Dixon B, Alamu OE, Asiedu R (2010) Identification and quantification of major carotenoids of deep yellow-fleshed yam (tropical Dioscoreadum etorum). Journal of Food, Agriculture and Environment 8: 160-166
Forbes-Hernández TY, Gasparrini M, Afrin S, Cianciosi D, González-Paramás AM, Santos-Buelga C, Mezzetti B, Quiles JL, Battino M, Giampieri F, Bompadre S (2017) Strawberry (Cv. Romina) Methanolic Extract and Anthocyanin-Enriched Fraction Improve Lipid Profile and Antioxidant Status in HepG2 Cells. International Journal of Molecular Sciences 18: 149-157.

Giusti MM, Wrolstad RE (2005) Characterization and measurement of anthocyanins by UV-visible spectroscopy. Unit F1.2. In: Wrolstad RE, Schwartz SJ, editors. Handbook of Food Analytical Chemistry. New York: John Wiley \& Sons Inc. Pp 19-31

Hasan SM, Ngadin AA, Shah RM, Mohamad N (2008) Morphological Variability of Greater Yam (Dioscorea alata L.) in Malaysia. Plant Genetic Resources: Characterisation and Utilisation $6: 52-61$

He J, Giusti MM (2010) Anthocyanins: Natural Colourants with Health-Promoting Properties. Annual Review of Food Science and Technology 1: 163-87.

Holick CN, Michaud DS, Stolzenberg-Solomon R, Mayne ST, Pietinen P, Taylor PR, Virtamo J, Albanes D (2002) Dietary carotenoids, serum beta-carotene, and retinol and risk of lung cancer in the alpha-tocopherol, beta-carotene cohort study. American Journal of Epidemiology 156:536-47

IPGRI/IITA (1997) Descriptors for Yam (Dioscorea spp.). International Institute of Tropical Agriculture, Ibadan, Nigeria/ International Plant Genetic Resources Institute, Rome, Italy.

Jesus M, Martins AP, Gallardo E, Silvestre S (2016) Diosgenin: Recent Highlights on Pharmacology and Analytical Methodology. Journal of Analytical Methods in Chemistry 41:562-593

Jyothy A, Sheela MN, Radhika NK, Anwar I (2017) Morphological Characterization of Greater Yam ( Dioscorea alata L .) Landraces in Kerala. Journal of Root Crops 43: 3-10.

Kumar S, Das G, Shin HS, Patra JK (2017) Dioscorea spp. (A Wild Edible Tuber): A Study on Its Ethnopharmacological Potential and Traditional Use by the Local People of Similipal Biosphere Reserve, India. Frontiers in Pharmacolgy 8:52-59

Lubag Angelo JM, Laurena AC, Tecson-Mendoza EM (2008) Antioxidants of Purple and White Greater Yam (Dioscorea alata L.) Varieties from the Philippines. Philippine Journal of Science 137: 61-67

Michel KA, Brice DKE, Boni N, Sidoine EB, Pierre ZG (2015) Dichotomous Key Determining Varietal Groups of Yam Species Dioscorea alata L. Greener Journal of Agricultural Sciences 5:190-203. 
Ozgen M, Joseph CS, Neil RR, Miller R (2010) Total Phenolic, Anthocyanin Contents and Antioxidant Capacity of Selected Elderberry (Sambucus Canadensis L.) Accessions. Pharmacognosy Magazine 6: 198-209

Pekal A, Pyrzynska K (2014) Evaluation of Aluminium Complexation Reaction for Flavonoid Content Assay. Food Analytical Methods 7:1776-1782

Rodriguez-Amaya DB, Kimura M (2004) Harvestplus Handbook for Carotenoid Analysis. HarvestPlus Technical Monograph 2. Washington, DC, and Cali., International Food Policy Research Institute (IFPRI) and International Center for Tropical Agriculture (CIAT).

Sajjaanantakul TT, Likitwatanasade S, Idhipon SS, Hongsprabhas P (2014) Effect of Storage Conditions on Phenolic Compounds and Antioxidant Capacity of Thai Yam (Dioscorea alata L.) Tubers. Agricultural Sciences: Leading Thailand to World Class Standards. Proceedings of the 52nd Kasetsart University Annual Conference, Kasetsart University, Thailand. Vol. 6: Agro-Industry, 114-21.

Sellappan S, Akoh CC, Krewer G (2002) Phenolic compounds and antioxidant capacity of Georgia-grown blueberries and blackberries. Journal of Agricultural and Food Chemistry 50:2432-2438.

Sindhi V, Gupta V, Sharma K, Bhatnagar S, Reeta Kumari, Dhaka N (2013) Potential Applications of Antioxidants - A Review. Journal of Pharmacy Research 7: 828-35.

Sing RP, Chidambara Murthy KN, Jayaprakash GK (2002) Studies on the antioxidant activity of pomegranate peel and seed extracts using in vitro models. Journal of Agricultural and Food Chemistry 50: 81-86.

Siqueira MVBM (2017) Yam: A Neglected and Underutilized Crop in Brazil. Horticultura Brasileira 29: 16-20.

Sreeramulu D, Raghunath M (2010) Antioxidant Activity and Phenolic Content of Roots, Tubers, and Vegetables Commonly Consumed in India. Food Research International 43: 1017-1020.

Tang Y, Weixi C, Xu B (2015) Profiles of Phenolics, Carotenoids and Antioxidative Capacities of Thermal Processed White, Yellow, Orange and Purple Sweet Potatoes Grown in Guilin, China. Food Science and Human Wellness 4: 123.

Tewodros M, Mekbib F, Shimelis H, Gebre E, Amelework B (2018) Genetic diversity of yam (Dioscorea spp.) landrace collections from Ethiopia using simple sequence repeat markers. Australian Journal of Crop Science 12:1223-1233.

Ukom AN, Ojimelukwe PC, Ezeama CF, Ortiz DO, Aragon IJ (2014) Phenolic Content and Antioxidant Activity of Some Under-Utilized Nigerian Yam (Dioscorea spp.) and Cocoyam Xanthoso mamaffa (Scotts) Tubers. IOSR Journal of Environmental Science, Toxicology and Food Technology 8: $104-111$.

Yu L, Haley S, Perret J, Harris M, Wison J, Qian M (2002) Free radical scavenging properties of wheat extracts. Journal of Agricultural and Food Chemistry 50:1619-1624.

Zhishen J, Mengcheng T, Jianming (1999) The determination of flavonoid contents in mulberry and their scavenging effects on superoxide radicals. Food Chemistry 64:. 555- 559. 